most of them have come to similar conclusions." While it is true that scientific progress depends on evidence and not on votes, it seems to me that this attempt to influence opinion by invoking weight of numbers is unfair in that it involves reputations as well as hypotheses. I have therefore ascertained the facts by communicating with the members of the party-other than Professor Bailey himself and one member who is abroad. It turns out that it is not true "that most of them have come to similar conclusions".

In a recent article on "The Idea of Contrasted Differentiation" (GEoL. MAG., 1936, pp. 228-238), I have already given reasons for differing from Professor Bailey in the field of petrogenesis. Fortunately I need not enter into the technical details of the additional points raised in the Memorandum, since Miss Reynolds has clearly presented a host of relevant facts (in press, Geol. MaG., 1936), which, to my mind, effectively dispose of the criticisms offered. I wish, however, to place on record that since Miss Reynolds completed her field work on the eastern end of the Newry Complex, I have spent nearly three weeks on the ground, and examined all the thin sections that have been cut, as a result of which $I$ am in entire agreement with her statement of the evidence, and with the straightforward and objective interpretation of that evidence which she has given.

Dr. Alfred Brammall, who collected critical specimens from the Newry Complex, and has since examined them-particularly for evidence of the syntectic processes postulated by Miss Reynolds, has invited me to add that he, too, is in entire agreement with her interpretation.

Science Laboratories,

Arthur Holmes, University of Durham.

18 th June, 1936.

DURHAM.

\title{
ON BABABUDANITE.
}

SIR,-I have read the letter of Mr. B. Rama Rao in the April number of the Geological Magazine, and though reluctant to take up space on a matter of somewhat local importance, I consider it necessary to correct certain wrong impressions that this letter gives.

Mr. Rama Rao's letter would seem to suggest that I was not aware of Jayaram's statement that bababudanite was probably a secondary metamorphic mineral. I have discussed this matter elsewhere ${ }^{1}$ and so shall content myself here by stating that Jayaram's was a mere suggestion unsupported by either field or microscope evidence. I

1 Current Science, iii, 1935, 608. 
submit that mine remains tbe only detailed work ${ }^{1}$ on the Bababudan area which has clearly shown the secondary nature of this mineral.

I am more than surprised, however, at the latter part of Mr. Rama Rao's letter where he states that the "ferruginous amphiboles have been long regarded in Mysore as secondary minerals of metamorphic origin ". If this were the case, why did Mr. Rama Rao himself, as recently as 1934, write as follows in regard to cummingtonite? "A reference to the previous publications of the Mysore Geological Department on the genesis of this mineral indicates that in all the recorded instances it has been considered as the original remnant constituent of a cummingtonite rock, due to the breaking down of which many of the 'ferruginous quartzites' of Mysore are believed to have been formed," 2 and again, "contrary to the usually accepted view of the original character of the mineral in Mysore. . . ."3 (Italics mine.)

The history of these ferruginous a mphiboles in Mysore is intimately connected with that of the iron formations, and it is significant that as late as 1932, Mr. Sampat Iyengar, who was then the Director of Geology in Mysore, attributed the formation of ferruginous quartzites to the metasomatic alteration of original cummingtonite schists. ${ }^{4}$ Again, in 1934, the authors of a Mysore Geological Department Bulletin state that "cummingtonite schist has altered into ferruginous quartzite" ". I could give more instances, if need be, to prove that the Department (except for stray observations), never seriously countenanced the secondary character of these amphiboles till 1934, that is, a year after I had pointed out the metamorphic development of both bababudanite and cummingtonite in the banded ferruginous quartzites of the Bababudan Hills. ${ }^{6}$

C. S. Pichamuthu.

UNTVERSTTY OF MYSORE,

BANGALORE.

23rd April, 1936.

1 Half-Yearly Journ. Mysore Univ., viii, 1935.

2 Mysore Geol. Dept. Bulletin, No. 15, 1934, 23-34.

3 Ibid., 33.

4 Rec. Mys. Geol. Dept., xxx, 1932, 15.

5 Mys. Geol. Dept. Bulletin, No. 14, 1934, 11

${ }^{6}$ Current Science, i, 1933, 276-7. 